Prof. Longina

Strumska-Cylwik

Division of General

Pedagogy,

Social Science Faculty,

University of Gdańsk,

Poland

I.strumska@ug.edu.pl

Prof. Bert Olivier

Department of

Philosophy,

University of the Free State,

Bloemfontein, South

Africa

OlivierG1@ufs.ac.za

DOI: https://dx.doi. org/10.18820/24150525/

Comm.v23.13

ISSN 2415-0525 (Online)

Communitas 2018

23: 194-206

(c) Creative Commons With Attribution (CC-BY)

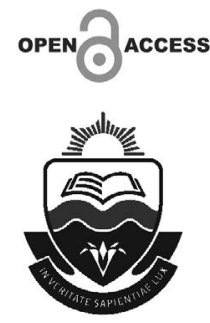

\section{WHAT ARE THE IMPLICATIONS OF CELEBRITIES 'BEHAVING BADLY' ONLINE?}

\section{ABSTRACT}

With a specific online article as point of departure, this article ${ }^{1}$ investigates the phenomenon of "bad behaviour" on the part of socalled "celebrities" online. It focuses on the article in question to be able to show what is at stake, namely, the fact that ordinary people are affected by celebrities' online actions, specifically in the form of either confusion regarding their own behaviour, or by imitating the actions concerned. This is followed by raising questions regarding online behaviour and "normalisation" and exploring these through the work of relevant authors such as Goffman (2006), Maisonneuve (1995), Huizinga (2007) and others, with a view to make sense of the fact that even supposedly shocking behaviour on the part of celebrities seems to be judged in terms of different criteria compared to everyday actions on the part of ordinary people. The role of advanced electronic technology in affecting people's behaviour is also noted, before turning to Plato and (particularly) Aristotle's notion of mimesis (imitation) to be able to understand what might be termed the "celebrity effect". The related question of identification with the images of celebrities is also briefly examined before concluding with a reference to Boorstin's (1992) famous account of a "celebrity".

Keywords: online communication; mass communication; media texts; communicational interaction; image studies; visual communication; celebrity; identity studies; mediated communication

\section{INTRODUCTION}

In an article on the Yahoo Style website, Marie Claire Dorking (2017) claims that when so-called "celebrities" - arguably the contemporary kitsch counterparts of ancient Greek Olympians - "behave badly" online, their behaviour has a recognisable impact on the behaviour of ordinary people, including children. In other words, the bad example they set has consequences when it comes to children's informal education - what is communicated to them about how to act appropriately as human beings from the world around them. This is hardly surprising, considering that even most adults are generally impressionable when it comes to "celebrities" (in a culture that valorises the latter), and children are understandably more so. 
Dorking relates how celebrity Rob Kardashian launched a disturbingly graphic onslaught on his former fiancée, Blac Chyna, on Instagram, which led to the suspension of his Instagram account (Mail Online 2017). Not that it mattered; he simply transferred his assault to Twitter, to be witnessed by millions of followers. She further reminds her readers that this kind of online "bad behaviour" has been going on for some time between so-called celebrities, including Taylor Swift and Nicki Minaj - it is nothing unusual, except that it has consequences. Here we have to quote Dorking (2017) at length to be able to get across what is at stake:

Heck even the President of the US isn't exempt from behaving badly online. In fact Donald Trump's most popular tweet to date is a video that shows him fake-pounding a personification of CNN. OK so celebrities behaving badly is nothing new, but the way we learn about it is. Somehow social media has created a whole new platform for the naughtiness to be witnessed, shared and then interpreted in a series of funny memes. But what effect is all this virtual naughtiness having in the real world? At home children are consistently told that calling people names is unacceptable. At school a verbal attack on a classmate would result in punishment, bullying is not tolerated. Online, however, celebrities who slam other celebrities are rewarded with a trending hashtag and global attention. Go figure.

Dorking (2017) also cites two psychologists, who agree that such behaviour goes against the supposed educational consensus that children should be taught how to behave decently. Again, it is necessary to quote her in full:

'Over time, the attitudes and behaviors that we are concerned with right now in social media will bleed out into the physical world,' Karen North, a psychologist and director of the University of Southern California's Digital Social Media Program told Associated Press. 'We're supposed to learn to be polite and civil in society. But what we have right now is a situation where a number of role models are acting the opposite of that ... And by watching it, we vicariously feel it, and our own attitudes and behaviour change as a result.' Catherine Steiner-Adair, author of 'The Big Disconnect: Protecting Childhood and Family Relationships in the Digital Age,' believes the effects are already being witnessed. The psychologist says many of her students are confused about why celebrities and politicians can engage in namecalling and other unacceptable behaviour on social media without the punishment they would ordinarily receive.

It seems intriguing that behaving badly is acceptable online but not in real life. With Gadamer's (2004: 122) account of the etymology of the word "theory" in mind - that it derives from the ancient Greek word for a spectator at a drama or religious festival, namely "theoros" (who is present at a sacred event), and from "theoria" (as that which is "present to what is truly real") - one might be tempted to compare events witnessed in media, or online, with the sacred Ancient Greek Olympics. This festival, in honour of Zeus, created the opportunity for athletes from different Greek cities to compete but also for spectators to enjoy the competition. These games probably served different social and cultural purposes; they were a form of entertainment for the masses but also fulfilled sport-cultural and religious-ritual functions (see Penn Museum [1]), which did not prevent some athletes from surreptitiously accepting bribes to lie about their "polis" (city-state) of origin, however, in this way bathing their supposed home city in undeserved glory (Penn Museum [2]). 
By comparison (and contrast), the bad behaviour on the part of celebrities, in full mediated view of the (Twitter) "following" public today, is precisely a form of "cheap" entertainment, as the sustained attention to celebrity antics demonstrates. Furthermore, given the pervasive function of the media in contemporary culture, it is plausible to claim that, while there is (strictly speaking) nothing sacred about celebrities' behaviour, the avidity with which it is scrutinised and imitated by their followers (no doubt by way of identifying with them; see Dorking 2018) does bestow upon it the status of something pseudo-sacred despite being wholly secular. After all, celebrities are arguably the contemporary (secular) counterparts of the ancient Olympians (with sincere apologies to the latter). However, while the ancient "theoros" or spectator was present to and at the sacred athletic events, celebrity followers usually have only mediated access to celebrities' actions. Strictly speaking the formal rituals that accompanied ancient Greek Olympics - and still attach to contemporary Olympics - are largely absent from celebrity actions; of course, except if one were to argue that actions like the kind of ex-fiancée-bashing on the part of Rob Kardashian may be regarded as being itself a kind of pseudo-ritual that celebrities perform repeatedly in order to keep their followers' eyes glued to them.

\section{RESEARCH OBJECTIVE AND METHODOLOGY}

What this article proposes to do is to scrutinise the implications of the online actions on the part of celebrities by asking certain pertinent questions and attempting to answer these. Methodologically speaking the approach is largely hermeneutic (or interpretive) in the sense of textual interpretation (including that of images where these are concerned) of online material as well as of relevant theoretical texts. The authors are guided in this by Gadamer's (1982: 274-275) historical understanding of the "hermeneutic problem" as comprising the three components of understanding (implicit interpretation), interpretation (explicit understanding) and application (the relevance of the interpretation in question for the situation of the interpreter). Hence, as will become apparent in the course of the article, the interpretation offered of "bad online behaviour" on the part of celebrities will be brought to bear on the present (early $21^{\text {st }}$ century) situation of people who are familiar with the use of the internet and its potential influence on their own, and others' behaviour. Furthermore, the hermeneutic approach allows the authors, as in all cases of the interpretation of communicational phenomena, to avail themselves of various theoretical or interpretive perspectives to be able to make sense of the issue(s) under discussion.

\section{ONLINE BEHAVIOUR AND NORMALISATION}

Assuming that it is based on incontrovertible evidence, it is hard to disagree with the title of Dorking's article, that celebrities behaving badly online has a significant impact on the way people live in real life. From what she reports it is further clear that such online actions normalise, promote and reinforce negative behaviour patterns on the part of those who avidly "follow" the lives and actions of celebrities. What seems to be particularly worrisome is the endless popularity and huge interest that surround such behaviour in contemporary media, as evidenced by the high level of activity shown by 
online users (referred to later in the text). At the same time, the following questions arise: What are the right and the wrong forms of behaviour nowadays? Which norms do they relate to? Are we witnessing changes in norms? Or are we rather witnessing the emergence of new and at the same time different online standards (diverging from norms in force in real life)? Or maybe we are dealing with a transition from the ethical plane to the aesthetic or emotional one (in which the idea is to make a certain impression, to stimulate or trigger certain emotions through provocative and antisocial behaviour that breaks rules and moral norms).

Although it is difficult to answer these questions unambiguously, the authors are inclined to believe that communicational interactions on the internet are primarily concerned with aesthetic and emotional discourse, whereas ethical discourse seems to be insignificant in comparison. This appears to correspond broadly to Habermas's (1987: 121, 113-157) distinction between "strategic" and "communicative" (inter-) action, where the former serves the instrumental purpose of wielding power over interlocutors, while the latter represents a sincere attempt at communicating, providing, as far as possible, the grounds for claims, statements and arguments. By this we mean that such online behaviour appears to conform to expectations pertaining to aesthetic (that is, perceptually appealing) appearance and to the need to use it in such a way that the emotions of interlocutors (assuming there is a communicational exchange) and of the "following" public are strategically manipulated for the benefit of the celebrities concerned.

This is evidenced by numerous media presentations online, especially those that focus on problematic behaviour of celebrities (Dorking 2017), exacerbating the need for reflection on them. At the same time, another question arises (that in a sense refers to the authenticity and credibility of such behaviour), namely how the problematic behaviour of celebrities fits into the shape and the expectations of the contemporary culture they happen to live in. Is it possible that such behaviour is merely a response to this culture's specific (albeit tacit) needs at the aesthetic and emotional level, in which to attract attention to oneself - even by means of (sometimes extremely) shocking behaviour, usually in pursuit of "celebrity fame", no matter how ephemeral - means the same as "to be" or to exist (Benjamin 2015)?

It is worth noting here that celebrities (despite their problematic or reprehensible behaviour) seem not only to be significant figures in the modern world (defining legitimate ways and patterns of behaviour), but they also become new authorities (judges and public opinion leaders, as well as the embodiments of universally recognised style and taste, lifestyle, and sometimes even exemplary "morality" or a philosophy of life which offers itself for imitation and emulation). It is well-known that people have a strong need to belong to some group, or the need for affiliation, so they seek "emotional identification with other people to establish some sort of organic bond” (Burszta 1998: 164).

Celebrities, on the other hand, often become brands in and of themselves, so they can use their status to build their own empire and effectively attract people to themselves. It does not matter whether they are the ones with real merits or achievements, or 
only those who are "famous for being famous" (Boorstin 1992). It turns out that in contemporary mass culture there is a suitable place for both the former and the latter, and they play a significant role in the creation of public opinion. That is the reason why a number of companies as well as media (including social networks) are eager to use images representing the power of celebrities to successfully advertise almost anything (from promoting goods, articles or services to promoting specific behaviour, lifestyles or ways of co-existing with other people).

The increasing popularity of celebrities is associated with the rapid growth of social media, such as Twitter, Facebook and Instagram, in which they are willing to be used, and which enables companies and institutions to reach out to a wide range of audiences quickly and effectively. It turns out that celebrities and their images are a much more effective way to attract the attention of the audience than the usual advertising messages (EuroMonitor International 2014). Apparently, the example of celebrities exercises a strong and significant attraction for the lives of ordinary people who often draw "inspiration" from them, imitating and copying their ideas and behaviour. This is hardly surprising, given that celebrities are ubiquitous in the surrounding social world - especially in the world of media.

It is worth pointing out (Goffman 2006) that, generally, a person in his or her actions, behaviour and the roles they fulfil, follows and copies the existing social world (specific rules, patterns, traditions, ways of interacting, or fulfilling certain social roles in a given community and culture). This also applies to the phenomenon of mutual respect towards one another, which is governed largely by the cultural habitus and the rituals of behaviour that Maisonneuve (1995) has been paying particular attention to. With such rules and rituals, people's lives become more predictable, homely, domesticated or "tamed". They allow them to maintain a specific social order (in which they are chastised, among other things, for behaviours that are deemed in the cultural context to be undesirable, arrogant, impudent, eccentric, malignant, reprehensible, "out of place" and which, through existing rules, are properly sanctioned). In this way, the boundaries of proper and wrong behaviours are outlined, and the rules in force become, in a sense, instructions, signposts indicating how people should behave and deal with others or with their own emotions (Goffman 2006: 5-11, 66- 67; Maisonneuve 1995).

Contrary to the above (as noted in the article referred to earlier), and perhaps surprising to some, in the virtual world such broadly normative guidelines (and standards, rituals) are not generally applicable. Instead, contemporary social media have created a platform where almost anything can be presented, and that makes us more and more often aware of reprehensible and mischievous behaviour on the part of media users, particularly so-called celebrities. Paradoxically, such behaviour is rewarded with increased popularity, global attention of the audience and their intensified media activity, not only "liking" and "tweeting" but also sharing certain anti-social posts on social media with other users, converting them into a series of funny memes or even creating their own posts based on them - which can also be interpreted as a sign of creating a new form of entertainment. Usually it results in even greater popularity and interest in the presented forms of antisocial behaviour, and often in their imitation and transfer to the real world. As a consequence, it leads to the legitimation of reprehensible 
and antisocial behaviour in contemporary media (at the same time normalising and reinforcing it in everyday life). The recipients of the messages concerned not only interact with other audiences (exchange opinions with them), but they also create their own perspective on and version of the events in the form of produced posts or films (due to which they themselves become actors and creators of more or less sophisticated forms of entertainment or "fun" - which raises the question of what passes for fun).

In such a situation, it is difficult to resist North's fear (expressed in Dorking 2017) that "over time, the attitudes and behaviour that we are concerned with right now in social media will bleed out into the physical world". Such fears are neither groundless nor isolated, as we can see in Habermas's view that humanity has attained dominion over nature to a great extent, but passively adapts to the changes conditioned by technological progress in the social sphere (Reut 1995: 191-192). It is worth noting here that the concept of fun associated with the kind of media (and mediated) behaviour in question differs from its original understanding. It does not coincide with Huizinga's "homo ludens" concept, in which fun is an autotelic value (it is a purpose in itself) and as such lies at the base of human action, just like a competition or a game which in its original form is supposed to give a person a sense of satisfaction and fulfilment. Such fun, though based on voluntarily accepted rules, requires their mandatory fulfilment. It is also accompanied by an awareness of otherness in relation to normal life (Huizinga 2007: 15-37), unlike the phenomenon in question, which is worrisome precisely because - as North and others have observed - it "bleeds into" normal life.

Evidently, therefore, fun is understood differently in the presented perspective of media coverage online, which overthrows all "normal" social rules, and blurs the boundaries between truth and fiction, or the real world and the media. The only lasting and valid rule here is that there are no fixed rules, which means they can be freely changed and adapted to current needs. What strikes one is the inventiveness, if not arbitrariness, with which celebrities approach the question of their behaviour, or, for that matter, their creative activities, for example singer Miley Cyrus's "daring" appearance in the music video of her song "Wrecking Ball" (2013; Johns 2017).

Arguably this goes far beyond the manner in which avant garde modern art in the 20th century, according to Hughes (1991: Introduction), managed to sustain a constantly surprising and disorienting sense of "newness and possibility" before eventually "petering out" in institutionalised late modernism. Therefore, it is not surprising that the fun in such a context of what may be described as arbitrary invention is increasingly devoid of its original (autotelic) function: fun for the sake of fun (to bring spontaneous joy, satisfaction, contentment), and it is more and more often subordinated to something else. As a result, satisfaction and contentment are more and more often combined with, or dependent on, some specific, hidden conditions demanding to be fulfilled. At the same time, it requires continuous adaptation to new and constantly changing rules relating to how people should play, rest and relax, and what they should derive pleasure and satisfaction from (satisfaction with what kind of life, entertainment, mutual relations with other people, and so on). Every time a celebrity uses the internet 
to communicate yet another (in fact, supposedly more) "shocking" action compared to the previous one, on their part, it takes viewers, "followers" and the general public into more aesthetically and emotionally (and willy-nilly, also ethically) uncharted waters, such as when reality television star Kim Kardashian posts a nude photograph of herself climbing a tree in nothing but a pair of boots (Fox News 2017). For many "open-minded" people such an action is, in itself, no cause for concern - by now the way in which "celebrities" vie with one another for public attention is familiar to most people - but the "no holds barred" ethos (if one could call it that) underpinning such actions has consequences in social reality far beyond the confines of the internet, as the article referred to at the outset indicates.

Upon reflection, these considerations mean that fun, considered in such a perspective (released from the conventional rules in force), cannot be regarded as completely neutral and innocent, nor can the media coverage in question, which is an excellent medium for its propagation (given its often cheaply grounded sensation, based on many representations of inappropriate celebrity behaviour) and in this way the atmosphere of specifically conceived "entertainment" is built up. As Schulz von Thun (2001: 9-20) observes, there are no completely neutral or "empty" messages, but instead each of them (as well as every statement) serves something - it is always created for something, for some purpose and for someone. This means that each message conceals a specific intent, a specific purpose, an appeal that is subordinated to specific ideas, motives and expectations, implicitly demanding an appropriate response.

One also has to recognise that numerous media messages increasingly represent more and more risky and extreme (often anti-social) behaviour or actions to better engage and attract the attention of the audience and achieve the intended goals of those who post the messages most effectively. One of the notable examples of this is the "branding oneself" phenomenon (Olivier 2011), which manifests itself in reducing oneself to the status of a commodity for the use of others, and further reflects a modification of one's sense of self-worth. Furthermore, the willingness to provide a significant amount of information about oneself, including personal likes and dislikes, on a website, does not reveal a desire for privacy. On the contrary, such information deliberately posted on the internet clearly reflects what individuals want to reveal (or "show off") to anonymous others. At the same time, we recognise that this practice is observed quite commonly, not only in the celebrity environment, but also among the so-called "common people" (Olivier 2011).

As pointed out by numerous studies, modern technologies favour both the creation of such messages and the emergence of anti-social behaviour (aggressive and self-aggressive), especially on the part of young or immature users, who often do not notice hidden threats and accept the content they are offered with great trust and good faith (often treating them as harmless entertainment, fun and relaxation). However, technology is changing people, robbing them of their autonomy, dehumanising them and affecting their own sense of identity in unpredictable ways, as Stiegler (2013) argues at length, where he exposes the influence on the minds of consumers being targeted by the culture industry through technical communicational means. As he points out, consumers are driven back to their "minority" (the state of being unenlightened) 
through the use of what he calls "mnemo-technical devices" such as smartphones, laptops and tablets (Stiegler 2013: loc. 429-488; Olivier 2011; Strumska-Cylwik 2014; Aftab 2003). The phenomenon under discussion here, namely, the demonstrable effects of celebrity misbehaviour on online users, is just one of the manifestations of what Stiegler describes as the loss of "majority" or enlightenment. Elsewhere he describes current global developments as part of a process of "stupidification" that is occurring worldwide - in the context of the current "hyper-consumerist" and "addictogenic" society, because of the increasing reliance of consumers on the mnemo-technical devices referred to above, instead of one's own capacity for memory and understanding (Stiegler 2015: loc. 286).

Against this backdrop it is not surprising that online messages, (only) seemingly with impunity, move audiences into an enchanted world of media reality where the "impossible becomes possible" and "what is not allowed is allowed". It turns out that in the situation when their audience does not seem to be sufficiently aware that the images or content presented (e.g. the images of celebrities or stars) do not represent a "true" reflection of reality, but are merely a kind of created hyperreality (Baudrillard 2006: 151-158; Belting 2012: 23-25), they pose a particularly serious threat to members of such audiences. It happens especially when the untrue, inauthentic worlds that are presented in them are based on intentionally created scenes, events or pictures, for example pictures, backgrounds and people perfected by software (such as Photoshop) procedures, or based on enhanced, idealised versions of events that make us think that the lives of celebrities are light, easy, pleasant and uncomplicated (which, as a result, evokes in people the will or desire to follow their example, their lifestyle, to be like them). In such a situation, it is no surprise that celebrities are gaining even more power in the field of "ordinary", "grey" social reality or everyday life, giving recipients what they believe to be new life opportunities in their imagined worlds that, as Appadurai (1996: 29-39) noted, are built on available images in the media. They also give the recipients opportunities to create imagined identities that make them dream the dreams that have been unattainable so far (Appadurai 1996; Pucek 2005).

\section{HOW SHOULD ONE UNDERSTAND THE 'CELEBRITY EFFECT'?}

In the light of the above, no one should therefore wonder why the online actions of celebrities should have such a noticeable effect on other people's behaviour. This may be further substantiated by considering that, as both Plato, in the Ion (1997: 942-943) as well as in the Republic (1997: 1199-1207), and his pupil, Aristotle, in the Poetics (N.D.: 3308-3354), already pointed out more than 2000 years ago, people characteristically imitate. Although these two thinkers evaluated imitation differently, they agree on humans being what they called "mimetic" beings. Interestingly, they distinguished between "diegesis" (telling, narrating) and "mimesis" (imitating, showing, embodying, representing) - two concepts used to this day in literary and film theory. A particularly relevant observation by Aristotle in his Poetics (N.D.: 3312) casts light on the imitation and the images in question here, namely online users imitating the questionable actions of celebrities: 
...the instinct of imitation is implanted in man from childhood, one difference between

him and other animals being that he is the most imitative of living creatures, and through imitation learns his earliest lessons; and no less universal is the pleasure felt in things imitated. We have evidence of this in the facts of experience. Objects which in themselves we view with pain, we delight to contemplate when reproduced with minute fidelity: such as the forms of the most ignoble animals and of dead bodies.

Although Aristotle here comments on learning through imitation or reproduction, even where the reproduction in question is of nothing pleasant to behold (corpses, and so on), one might see in it something parallel to the less-than-commendable examples set by celebrities online: could it be that it is precisely the questionable character of their behaviour that those (particularly children) who copy celebrities find so compelling? After all, the "bad behaviour" in question consisted in a celebrity posting explicit images of another celebrity (Blac Chyna) described as "revenge porn" (Mail Online 2017) online, and it is telling that, since the time of Plato and Aristotle it has been known that images fascinate people, sometimes in an arguably morbid manner where certain images are concerned.

This is conspicuously related to the complex question of identification; an individual identifies with someone or something when he or she experiences him or her affirmatively via their image (either in direct perceptual terms or indirectly via a reproduced image) as embodying a desirable quality or attribute. The "locus classicus" in this regard is Lacan's (1977: 1-7) psychoanalytical study of the so-called "mirror stage", where he demonstrates that the infant's "therapeutic" identification with its own mirror image forms the basis of all subsequent identifications in the social sphere, precisely because this image represents a "fullness" or "wholeness" and unity that the physically awkward infant still lacks at that stage, and therefore desires. If one adds to this Nancy's (2005: 6; see also Olivier 2009) contention, based on his phenomenological examination of the image, that images are characteristically "desirable", it is not difficult to understand the tendency, on the part of particularly young and inexperienced online users, to be attracted to the questionable images available to them on many online websites.

\section{CONCLUSION}

Does all of this seem familiar? How many of us have viewed a favourite movie or series several times, if only for that vicarious thrill one experiences when your favourite character(s) performs actions that one can, and does, identify with? It is a safe bet that many people do this. Why? Because it is a mimetic enjoyment - when I see the character of Sun Bak (a superior martial arts exponent) defending one of her "cluster" of "sensates" in the Wachowskis' television series Sense8 (Wachowski et al. 2015) against the people who are hunting them just because they are "different" from other human beings, she "embodies" the "difference" that I value in people, and ineluctably I identify with her in the narrative, but particularly via her image. The reason is that the latter constitutes a locus with which one identifies in a more-or-less "direct" manner. 
But this does not only happen in movies; it happens when we read novels (at the level of diegesis, with one's imagination supplying the iconic site of identification), and also in real life (Lacan 1977), where one identifies with an older sister or brother, or with a good chess player, or sports personality. The latter brings us back to the (largely) virtual sphere of (among others sports) celebrities, because arguably comparatively few people today identify with the captain of a school sports team, or the school's top academic scholar. Our lives in the culture of what Castells (2010: 355) calls "real virtuality" - the fact that virtual reality, or cyberspace, permeates our otherwise "real" lives - are shot through with the images of celebrities engaging in all kinds of actions, mostly intended to bring them the sustained attention of their "followers" on Twitter and other media. And as we know from Aristotle and Plato, for better or worse, being mimetic creatures, most people identify with, and worse, actually and actively imitate them, no matter how questionable their behaviour might be.

That "celebrities" - or rather, their mediated images - are the ones with whom people, including children, identify these days, leading to a kind of "cognitive dissonance" on the part of those who identify with them, is highly ironic, considering what a "celebrity" is. Contrary to what many people think, celebrities are not a very recent phenomenon - celebrities go back to at least the middle of the previous century. This much is evident from the work of Boorstin (1992: 57; italics in original), who defines a celebrity as follows (1992: 57; italics in original): "The celebrity is a person who is known for his [or her] well-knownness". Needless to stress, this is tautologous, but deliberately and unavoidably so, because, as Boorstin shows, unlike people who have become famous for their deeds, discoveries, literary, scientific, philosophical, cinematic and/ or other cultural achievements and contributions - such as Plato, Shakespeare, Mary Wollstonecraft, Einstein, Amelia Earhart, Laurence Olivier, Gandhi, Mandela, Luce Irigaray, and many others like them - the only thing that a celebrity is well-known for, is that they are well-known, and not for any concrete, lasting (constructive) contribution to society.

It is worth mentioning that not all celebrities are associated exclusively with negative forms of behaviour/action. Many of them also play a positive role (taking part in social campaigns, charities, promoting healthy lifestyles and socially desirable behaviour). A representative example is chef Jamie Oliver, who promotes and implements the so-called "healthy way" of eating in British schools (whose activity has been oriented towards chasing children away from unhealthy eating habits, encouraging them to eat vegetables, fruit and healthy food).

\section{ENDNOTES}

1 The financial support of the National Research Foundation of South Africa, as well as of the University of the Free State, which contributed to making the research relating to this article possible, is hereby gratefully acknowledged. 


\section{REFERENCES}

Aftab, P. 2003. Internet a dzieci. Uzależnienia i inne niebezpieczeństwa [Parent's guide to protecting your children in cyberspace]. (Translated by Nicewicz, B.). Warszawa: Wydawnictwo Prószyński i S-ka.

Aristotle. No date. Works. (Translated and edited by Ross. W.D.). [Online]. Available at: http:// www.holybooks.com/completes-aristotle-pdf/ [Accessed on 7 September 2017].

Appadurai, A. 1996. Modernity at large: Cultural dimensions of globalization. Minneapolis: University of Minnesota Press.

Baudrillard, J. 2006. Społeczeństwo konsumpcyjne. Jego mity i struktury, (La sociĕte de consommation, ses mythes, ses structures). (Translated by Królak, S. Warszawa). Wydawnictwo Sic!

Belting, H. 2012. Antropologia obrazu. Szkice do nauki o obrazie, (Bild-Anthropologie. Entwürfe für eine Bildwissenschaft). (Translated by Bryl, M. Kraków). Wydawnictwo UNIVERSITAS.

Benjamin, K. 2015. 5 destructive sides of celebrity culture no one talks about. Cracked, 27 October. [Online]. Available at: http://www.cracked.com/blog/5-destructive-sidescelebrity-culture-no-one-talks-about/ [Accessed on 7 September 2017].

Boorstin, D.J. 1992. The image - A guide to pseudo-events in America. New York: Vintage Books.

Burszta Wojciech, J. 1998. Globalizacja i nowa lokalność, in Antropologia kultury, Poznań.

Castells, M. 2010. The rise of the network society. (Second edition). Oxford: WileyBlackwell.

Cyrus, M. 2013. 'Wrecking Ball'. Music video, YouTube. [Online]. Available at: https://www. youtube.com/watch?v=My2FRPA3Gf8 [Accessed on 7 September 2017].

Dorking, M.C. 2017. Celebrities behaving badly online is having an impact in real life. Yahoo Style, UK, 11 July. [Online]. Available at: https://uk.style.yahoo.com/celebritiesbehaving-badly-online-impact-real-life-101017019.html?soc_src=mail\&amp;soc_ trk=ma [Accessed on 7 September 2017].

Dorking, M.C. 2018. Bride-to-be calls off her wedding after guests refuse to pay GBP1200 towards it, Yahoo Style, UK, 28 August. [Online]. Available at: https://uk.style.yahoo. com/bride-calls-off-wedding-guests-refuse-pay-1200-towards-092641948.html [Accessed on 28 August 2018].

EuroMonitor International. 2014. Celebrity power and its influence on consumer behaviour. [Online]. Available at: http://www.euromonitor.com/celebrity-power-and-itsinfluence-on-global-consumer-behaviour/report [Accessed July 2017].

Fox News. 2017. Kim Kardashian posts nude photo of her climbing tree on Instagram. [Online]. Available at: http://www.foxnews.com/entertainment/2017/09/06/kimkardashian-posts-nude-photo-her-climbing-tree-on-instagram.html [Accessed July 2017].

Gadamer. H-G. 1982. Truth and method. (Translated and edited by Barden, G. \& Cumming, J.). New York: Crossroad. 
Gadamer, H-G. 2004. Truth and method. (Second, revised edition). (Trans. rev. Weinsheimer, J. \& Marhall, D.G.). New York: Continuum.

Goffman, E. 2006. Rytuał interakcyjny (Interaction Ritual). (Translated by Szulżycka, A. Warszawa). Wydawnictwo Naukowe PWN.

Habermas, J. 1987. The theory of communicative action, Vol. 2. (Translated by McCarthy, T.) Boston: Beacon Press.

Hughes, R. 1991. The shock of the new. (Second edition). New York: McGraw-Hill, Inc. (Kindle edition).

Huizinga, J. 2007. Homo ludens. Zabawa jako źródło kultury (Proeve eener bepaling van het spel-element der cultuur [Homo ludens. A study of the play element in culture]. (Translated by Kurecka, M. \& Wirpsza, W.) Warszawa: Wydawnictwo ALETHEA.

Johns, G. 2017. Miley Cyrus on infamous 'Wrecking Ball' music video: 'I'm never living that down'. [Online]. Available at: https://www.aol.com/article/entertainment/2017/05/17/ miley-cyrus-regrets-wrecking-ball/22095384/

Lacan, J. 1977. The mirror stage as formative of the function of the I as revealed in psychoanalytic experience. In: Écrits: A selection. (Translated by Sheridan, A.) New York: W.W. Norton.

Mail Online. 2017. [Online]. Available at: http://www.dailymail.co.uk/tvshowbiz/ article-4668150/Rob-Kardashian-posts-explicit-picture-Blac-Chyna.html [Accessed on 7 September 2017].

Maisonneuve J, 1995, Rytuały dawne $i$ współczesne, (Les rituels). (Translated by Marta Mroczek). Gdańsk: Gdańskie Wydawnictwo Psychologiczne.

Mimesis. New World Encyclopedia. [Online].Available at: http://www.newworldencyclopedia. org/entry/Mimesis\#Aristotle [Accessed on 7 June 2017].

Nancy, J-L. 2005. The ground of the image. (Translated by Fort, J.) New York: Fordham University Press.

Olivier, B. 2009. That strange thing called 'identifying'. South African Journal of Psychology 39(4): 407-419. Reprinted in: Olivier, B. 2012. Intersecting philosophical planes philosophical essays. London and Frankfurt: Peter Lang Academic Publishers.

Olivier, B. 2011. Facebook, cyberspace, and identity. Psychology in Society, January. [Online]. Available at: http://www.scielo.org.za/scielo.php?script=sci arttext\&pid=S1015-60462011000100004 [Accessed January 2015].

Penn Museum (1). University of Pennsylvania Museum of Archaeology and Anthropology. [Online]. Available at: https://www.penn.museum/sites/olympics/olympicorigins. shtml [Accessed on 11 October 2017].

Penn Museum (2). University of Pennsylvania Museum of Archaeology and Anthropology. [Online]. Available at: https://www.penn.museum/sites/olympics/ olympiccommercialism.shtml [Accessed on 11 October 2017].

Plato. 1997. Complete works. (Ed. Cooper, J.M.) Indianapolis: Hackett Publishing Company.

Pucek, Z. 2005. Tożsamość wielokulturowej przestrzeni, Euro-limes - number 1(5) styczeń, Katedra Studiów Europejskich Akademii Ekonomicznej w Krakowie; website: www.euro-limes.ae.krakow.pl 
Reut, M. 1995. Krytyka, społeczeństwo, etyczność (filozoficzny kontekst pytań o krytyczność pedagogiki), in: Odmiany myślenia o edukacji, collective work, ed. Rutkowiak, J. Kraków: Oficyna Wydawnicza IMPULS.

Shulz von Thun, F. 2001. Miteinander Reden 1 (Sztuka rozmawiania, część 1). (Translated by Piotr Wołdyga). Kraków: Wydawnictwo WAM.

Stiegler, B. 2013. What makes life worth living: On pharmacology. (Translated by Ross, D.) Cambridge: Polity Press (Kindle edition).

Stiegler, B. 2015. States of shock: Stupidity and knowledge in the 21st century. (Translated by Ross, D.) Cambridge: Polity Press (Kindle edition).

Strumska-Cylwik, L. 2014. Młodzież w cyberprzestrzeni w kontekście 'jawnych 'i 'ukrytych' przekazów medialnych - szanse i zagrożenia wirtualnych światów, in: Молодіжна політика. Проблеми і перспективи, Дрогобич - Przemyśl, Number 5, PWSW, pp. 311-315.

Wachowski, L., Wachowski, L., McTeigue, J., Tykwer, T. \& Glass, D. (dirs). 2015. Sense8. USA: A Netflix Original television series. 